\title{
Wers i wiersz jako praca street art. O Sezonie Rafała Wojaczka
}

\author{
Joanna Dembińska-Pawelec
}

\author{
ORCID: 0000-0001-7242-381X
}

14 maja 2021 roku na terenie mikołowskich Plant odbyło się uroczyste otwarcie „schodów Wojaczka" - instalacji autorstwa Roberta Gilarskiego prezentującej wiersz tego poety zapisany na stopniach parkowych schodów ${ }^{1}$. Instytut Mikołowski im. Rafała Wojaczka upamiętnił w ten niecodzienny i artystyczny sposób pięćdziesiątą rocznicę śmierci poety urodzonego i mieszkającego wiele lat w Mikołowie ${ }^{2}$. Dyrektor Instytutu, Maciej Melecki, wybrał do wizualizacji streetartowej wiersz zatytułowany Sezon, który otwierał debiutancki tom Wojaczka³. Utwór od początku przyciągał uwagę krytyków i badaczy, skłaniał do interpretacji, uwagi na jego temat można odnaleźć w wielu artykułach i szkicach. Wybór tekstu do instalacji wydawał się zatem niemal oczywisty, ale być może rolę odegrały również inne względy. Sezon rozpoczyna się słowami: „Jest poręcz / ale nie ma schodów"4. Komunikat o tej treści zamieszczony w parku na zadbanych, szerokich, kamiennych schodach wyposażonych w dwie solidne poręcze wchodzi w kolizję z percepcją przechodnia, wydaje się absurdalny, intryguje, zaciekawia, wciąga czytelnika w grę znaczeń. Spacer po wznoszących się powoli stopniach przekształca się w wędrówkę po tekście, peregrynację po kolejno na-

\footnotetext{
${ }^{1}$ Dokumentację fotograficzną z otwarcia instalacji „schodów Wojaczka” autorstwa Roberta Gilarskiego można zobaczyć na stronie internetowej Instytutu Mikołowskiego im. Rafała Wojaczka: http://www. instytutmikolowski.pl/galeria-instytutu\#gallery-649699-13. Oprócz „schodów Wojaczka” odsłonięto także mural z podobizną Rafała Wojaczka również autorstwa Roberta Gilarskiego: http://www.instytutmikolowski.pl/ galeria-instytutu\#gallery-716510-10.

${ }^{2}$ Wiele faktów związanych z mikołowskim okresem życia Wojaczka podaje w książce Konrad Wojtyła, Antyantychryst? Wojaczek religijny (Mikołów: Instytut Mikołowski, 2021), 65-103.

${ }^{3}$ Pierwodruk Sezonu Wojaczka miał miejsce na łamach miesięcznika „Odra” w lutym 1966 roku. W stosunku do edycji z tomiku występują pewne różnice tekstowe. W egzemplarzu „Odry” będącym własnością Wojaczka pod wierszem w odręcznym dopisku poety odnotowana została data powstania Sezonu: „kwiecień 1965”. Dziękuję Maciejowi Meleckiemu za udostępnienie materiałów źródłowych.

${ }^{4}$ Rafał Wojaczek, „Sezon”, w Wiersze, wybrał i posłowiem opatrzył Tadeusz Pióro (Warszawa: Wydawnictwo PIW, 2004), 9. Cytaty z wiersza podaję za tym wydaniem.
} 


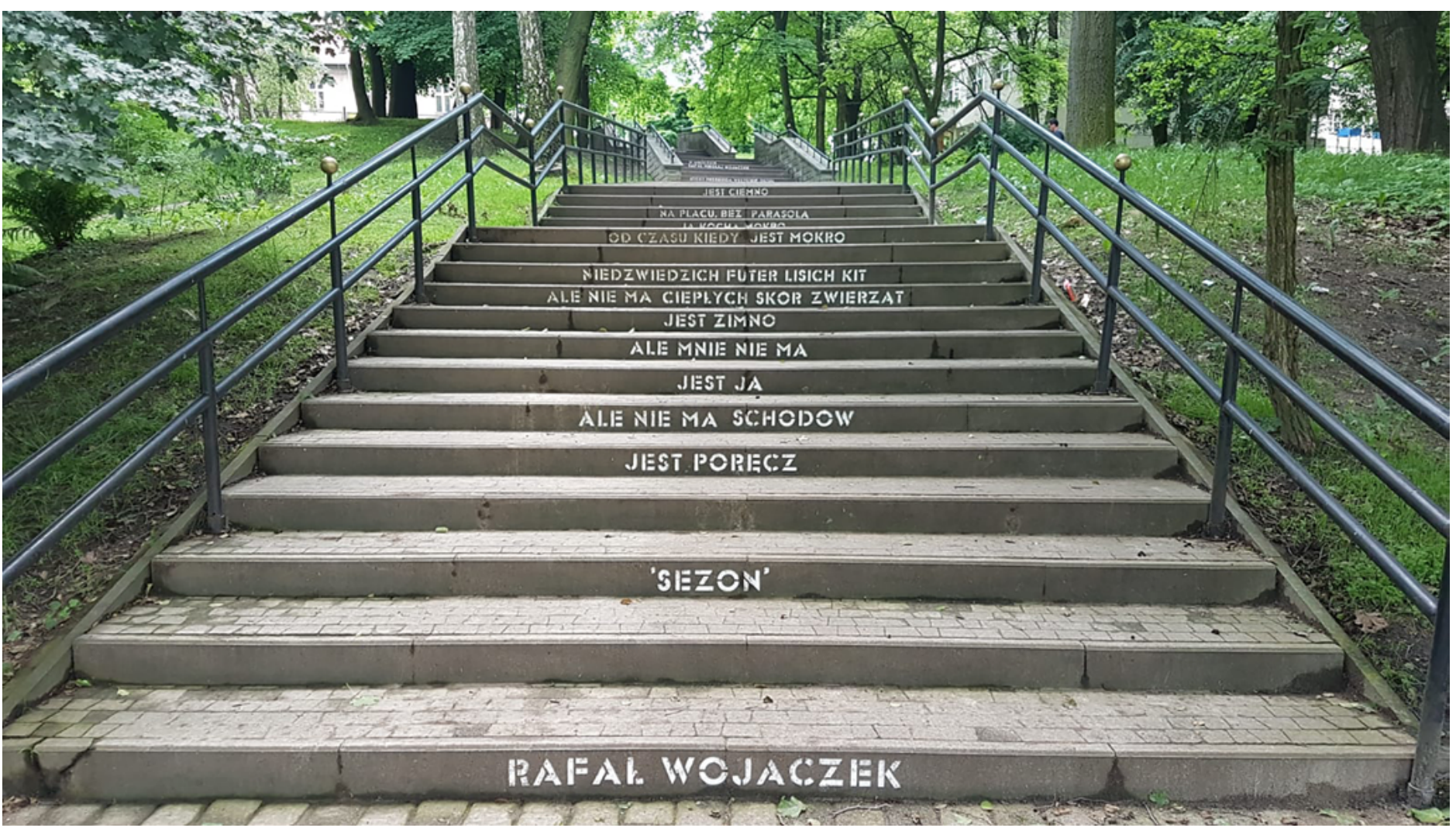

stępujących wersach wiersza. Czy kryje się w tej lekturze w przestrzeni miejskich Plant powrót do pierwotnego zamysłu pisma, o którym wspominał autor gramatologii ${ }^{5}$ ?

Zapisany na mikołowskich schodach utwór jest pierwszym, tytułowym wierszem z debiutanckiego tomu Sezon, wydanego przez Wydawnictwo Literackie w Krakowie w 1969 roku, zarazem otwiera także poetycki cykl zatytułowany Martwy sezon. Wojaczek napisał Sezon w postaci wiersza wolnego ${ }^{6}$, przypominającego typ różewiczowski, ewokujący, jak chciał Sławiński, retorykę bezradności. Świadomie wypracowana przez mikołowskiego poetę forma ma zasadnicze znaczenie dla semantyki utworu.

Jest poręcz

ale nie ma schodów

Jest ja

ale mnie nie ma

Jest zimno

ale nie ma ciepłych skór zwierząt

niedźwiedzich futer lisich kit

Od czasu kiedy jest mokro

jest bardzo mokro

5 Jacques Derrida, O gramatologii, tłum. Bogdan Banasiak (Łódź: Wydawnictwo Officyna, 2011), 359-374.

${ }^{6}$ Warto podkreślić, że w twórczości Wojaczka wiersz wolny frekwencyjnie nie należy do najczęściej występujących. Jak ukazuje Romuald Cudak, w jego poezji dominuje regularny wiersz stroficzny. Zob. Romuald Cudak, „Studium o wierszu Rafała Wojaczka”, w Inne bajki. W kregu liryki Rafała Wojaczka (Katowice: Wydawnictwo Uniwersytetu Śląskiego, 2004), 136-182. 


\author{
ja kocha mokro \\ na placu, bez parasola \\ Jest ciemno \\ jest ciemno jak najciemniej \\ mnie nie ma \\ Nie ma spać \\ Nie ma oddychać \\ Żyć nie ma \\ Tylko drzewa się ruszają \\ niepospolite ruszenie drzew \\ rodzą czarnego kota \\ który przebiega wszystkie drogi
}

Grzegorz Pertek w artykule z 2011 roku, obejmując horyzont twórczości autora Którego nie było, podkreślał szczególne znaczenie przywołanego utworu:

Słowa z wiersza Sezon Rafała Wojaczka [...] możemy dziś z całym przekonaniem uznać za jedną z najbardziej rozpoznawalnych poetyckich formuł, jakie wyszły spod pióra autora Innej bajki. Zapis »Jest ja / ale mnie nie ma« streszcza w sobie problematykę kryzysu tożsamości podmiotu od samego początku, od pierwszego liryku właściwie, przewijającą się między wersami przez cały dorobek poetycki wrocławskiego poety ${ }^{7}$.

Sezon jest świadectwem rozbicia osobowości, poczucia dezintegracji, wyobcowania i nietożsamości. Wyrasta z lęku, samotności, przeświadczenia, jak pisał Barańczak, że „własna egzystencja wydaje się czymś niepewnym”. Poeta, zauważał Paweł Dybel, „porzucając świat, w którym nie potrafi żyć, wobec którego czuje się bezradny, odnajduje drugi porządek", którym jest azyl własnej poezji .

Jacek Łukasiewicz zwracał uwagę na obecne w twórczości Wojaczka rozdwojenie na „ja” życiowe i „ja” poezji. Wyjaśniał ów fakt następująco:

Interesowała go [Wojaczka] przede wszystkim ontologia podmiotu liryki, pojętego jako podmiot wszystkich napisanych przez poetę wierszy, podmiot całego jego dzieła. Podmiot ten nie miał być rolą, [...] nie miał być również maską, zza której mówiłby rzeczywisty Wojaczek [...]. Nie; miał raczej stać się alter ego, drugim, lepszym, »ja « - uczynionym z rozmysłem. ${ }^{10}$

7 Grzegorz Pertek, „«Jest ja, ale mnie nie ma» - granica poetyckiego szaleństwa Rafała Wojaczka”, Przestrzenie Teorii, nr 16 (2011): 205.

8 Stanisław Barańczak, „Rafał Wojaczek. Metafizyka zagrożenia”, w Który jest. Rafał Wojaczek w oczach przyjaciót, krytyków i badaczy, red. Romuald Cudak i Maciej Melecki (Katowice-Mikołów: Wydawnictwo Uniwersytetu Śląskiego, Instytut Mikołowski, 2001), 100.

${ }^{9}$ Paweł Dybel, Ziemscy, słowni, cieleśni. Eseje o polskich poetach wspótczesnych (Mikołów: Instytut Mikołowski, 2019), 364.

${ }^{10}$ Jacek Łukasiewicz, „Liryka Rafała Wojaczka”, w Który jest. Rafał Wojaczek w oczach przyjaciót, krytyków i badaczy, red. Romuald Cudak i Maciej Melecki (Katowice-Mikołów: Wydawnictwo Uniwersytetu Śląskiego, Instytut Mikołowski, 2001), 162. 


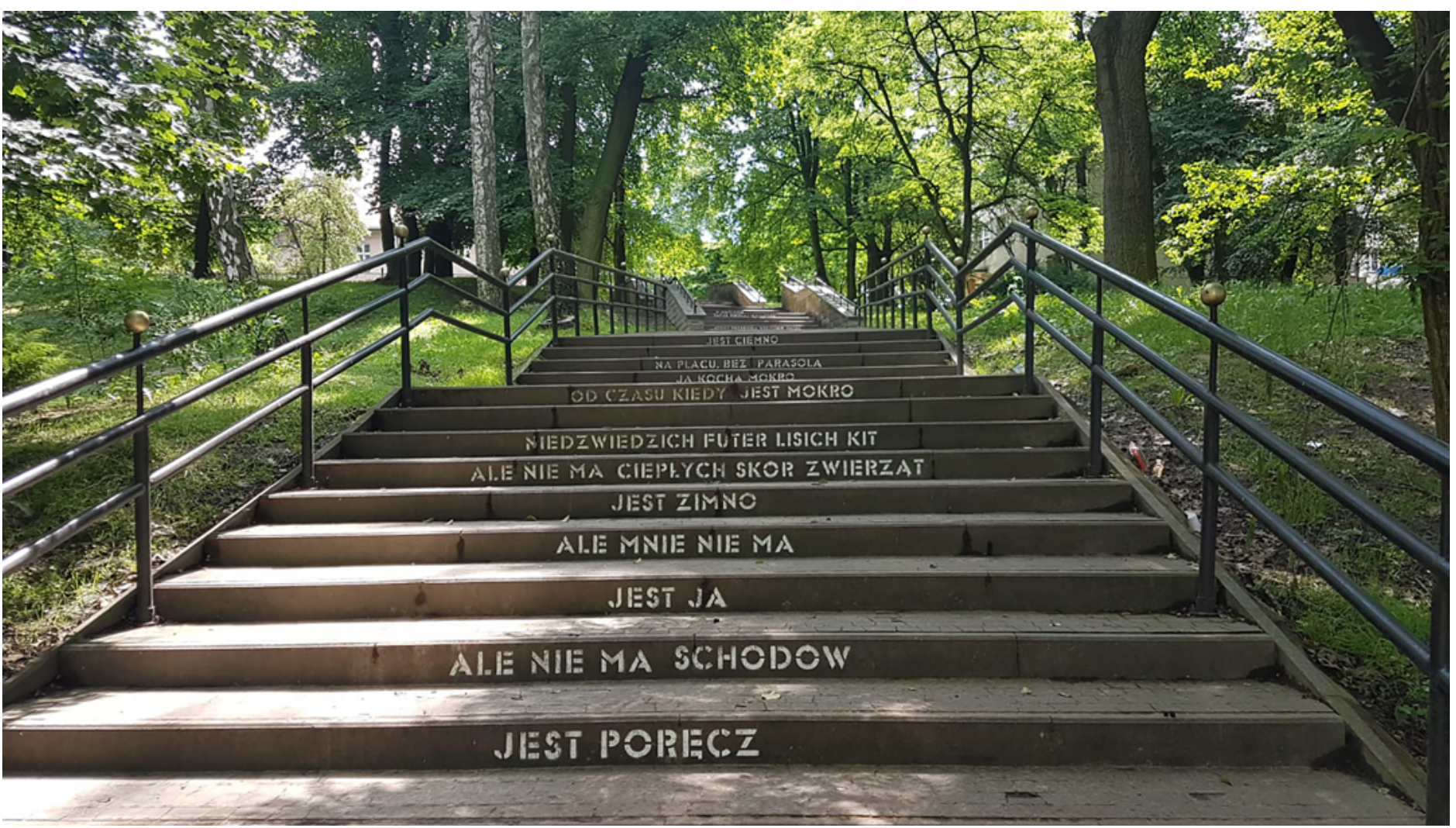

Słowa „Jest ja / ale mnie nie ma” są wyrazem rozdwojenia na „ja” $\mathrm{i}$ „ja” poezji, (w istocie niemożliwego) rozdziału życia i twórczości, egzystencji i kreacji artystycznej ${ }^{11}$. „Podmiot liryczny - pisał Tadeusz Komendant - okazuje się jedynym żywym naprawdę"12. Paradoks ten, zauważał, „wynika z totalnej niezgody na konwencjonalność i stagnację przeciętnego trwania, utożsamionego ze śmiercią"13. Podobnie Andrzej Niewiadomski pisał, że „»ja« staje się tu arbitralną konstrukcją odpowiadającą autonomicznemu statusowi podmiotu lirycznego, »mnie« zaś - spychaną na margines konkretną osobą, istniejącą wraz z namacalną cielesnością, chroniącą własną intymność i niepowtarzalność" ${ }^{14}$. Tomasz Kunz dostrzegał w zamierzeniu Wojaczka realizację transgresyjnego projektu poetyckiego, polegającego na zanegowaniu realności świata i własnej indywidualnej tożsamości oraz uczynieniu z twórczości jedynej możliwej przestrzeni autentycznego i autonomicznego istnienia ${ }^{15}$. W wierszu Sezon „pęknięcie między »ja« a »mnie« - tłumaczy - będące istotą wszelkiej świadomości, ujawnia bowiem głęboki »kryzys tożsamości«, stan tożsamościowego wyobcowania"16.

${ }^{11}$ Wielu krytyków i badaczy wskazywało na związek twórczości Wojaczka z życiem, inni podkreślali tekstowy charakter jego projektu poetyckiego. Konrad Wojtyła, analizując wypowiedzi na temat twórczości autora Sezonu, stanowczo opowiada się za uwzględnianiem kontekstu biograficznego poety, odrzucając wyłącznie literacką kreację „ja” poetyckiego. Zob. Konrad Wojtyła, Anty-antychryst? Wojaczek religijny, 48-56.

${ }^{12}$ Tadeusz Komendant, „Przywracanie symetrii. O poezji Rafała Wojaczka”, w Który jest. Rafał Wojaczek w oczach przyjaciót, krytyków i badaczy, red. Romuald Cudak i Maciej Melecki (Katowice-Mikołów: Wydawnictwo Uniwersytetu Śląskiego, Instytut Mikołowski, 2001), 104.

${ }^{13}$ Komendant, 104-105.

${ }^{14}$ Andrzej Niewiadomski, „Wojaczek: nieuchwytna cielesność, nieuchwytne ciało poezji”, Kresy, nr 4 (2007): 75.

${ }^{15}$ Tomasz Kunz, „Więcej niż słowa. «Nie skończona krucjata» Rafała Wojaczka”, w Interpretować dalej. Najważniejsze polskie książki poetyckie lat 1945-1989, red. Anna Kałuża, Alina Świeściak (Kraków: Towarzystwo Autorów i Wydawców Prac Naukowych Universitas, 2011), 288.

${ }^{16}$ Tomasz Kunz, „Liryka Rafała Wojaczka: przemiany podmiotu poetyckiego”, w Który jest. Rafał Wojaczek w oczach przyjaciót, krytyków i badaczy, red. Romuald Cudak i Maciej Melecki (Katowice-Mikołów: Wydawnictwo Uniwersytetu Śląskiego, Instytut Mikołowski, 2001), 222. 
Tytuł Sezon wiąże się bezpośrednio z nazwą cyklu, z którego ów wiersz pochodzi - Martwy sezon. Przede wszystkim jednak tytuł ten wskazuje na intertekstualny związek z utworem Arthura Rimbauda Sezon w piekle. W postaci francuskiego poety, zaliczanego do grona poètes maudits, niemal od początku dostrzeżono w Polsce literackiego patrona Wojaczka ${ }^{17}$. W odniesieniu do autora Nie skończonej krucjaty posługiwano się nawet sformułowaniem: „wrocławski Rimbaud”18. Już w słynnej nocie opublikowanej na łamach „Poezji” w 1965 roku, poprzedzającej debiut prasowy Wojaczka, Tymoteusz Karpowicz pisał: „Wiersze Wojaczka i klimat, w którym się rodzą, przypominają sprawy Rimbaudowskie"19. Podobnie we wstępie do Utworów zebranych Wojaczka notował:

„Z powinowactw konkretnych, literackich, oczywistym stał się tu wybór Rimbauda na patrona pióra poetyckiego i façon d'être. Sezon Wojaczka to świadome nawiązanie do Une Saison en enfer [...] Rimbaud ma swój sezon w piekle. [...] Wojaczek ma swój sezon z miejsca na ziemi”20.

Jan Błoński dostrzegał w poezji Wojaczka „nastrój prawdziwie przerażający” i zastanawiał się nad „rozpaczliwym zapisem doświadczeń wewnętrznych” ${ }^{21}$. W kontekście Sezonu zwracał uwagę na sytuację „wyobcowania, ale odczutego na poziomie najściślej cielesnym, najgłębiej osobistym"22 i przywoływał słynne zdanie Rimbauda napisane w liście do Jerzego Izambarda: „JA to ktoś inny” (JE est un autre) ${ }^{23}$. Warto zacytować większy fragment tego listu:

Niesłusznie jest mówić: Ja myślę. Należałoby powiedzieć: Mnie myślą. Przepraszam za grę słów. JA to ktoś inny ${ }^{24}$.

Jean-Pierre Richard tłumaczył tę wypowiedź Rimbauda następująco:

Jeśli bowiem JA to ktoś INNY, to przecież „ja” zrodziło tego innego; a jednocześnie n i e mogło go zrodzić, ponieważ ów inny jest właśnie innym, istotą całkowicie nową i obcą. „Myśli się mnie” pisze Rimbaud, ale owo się to także ja; ta myśl jest jeszcze moja i bardziej niż kiedykolwiek moja. To paradoks nowego cogito - myśli się mnie, więc powstaję - będący kluczem do całej Rimbaudowskiej przygody ${ }^{25}$.

\footnotetext{
${ }^{17}$ Wojaczek jest autorem niepublikowanego za życia wiersza zatytułowanego Rimbaud, rozpoczynającego się słowami: „Śnił mi się Rimbaud”. Zob. Rafał Wojaczek, „Rimbaud”, w Reszta krwi, red. Maciej Melecki (Mikołów: Instytut Mikołowski, 1999), 37.

${ }^{18}$ Cudak, Inne bajki. W kręgu liryki Rafała Wojaczka, 30.

${ }^{19}$ Tymoteusz Karpowicz, „Debiuty. Rafał Wojaczek”, Poezja, nr 1 (1965): 65.

${ }^{20}$ Tymoteusz Karpowicz, „Sezon na ziemi”, w Który jest. Rafał Wojaczek w oczach przyjaciót, krytyków i badaczy, red. Romuald Cudak i Maciej Melecki (Katowice-Mikołów: Wydawnictwo Uniwersytetu Śląskiego, Instytut Mikołowski, 2001), 131, 135.

${ }^{21}$ Jan Błoński, „Inne lęki, inne bajki”, w Który jest. Rafał Wojaczek w oczach przyjaciót, krytyków i badaczy, red. Romuald Cudak i Maciej Melecki (Katowice-Mikołów: Wydawnictwo Uniwersytetu Śląskiego, Instytut Mikołowski, 2001), 87.

${ }^{22}$ Błoński.

${ }^{23}$ Arthur Rimbaud, „List do Jerzego Izambarda, Charleville, 13 maja 1871 r”, tłum. Julia Hartwig, Artur Międzyrzecki, w Wiersze. Sezon w piekle. Iluminacje. Listy, wybrał, oprac. i posłowiem opatrzył Artur Międzyrzecki (Kraków: Wydawnictwo Literackie, 1993), 301.

${ }^{24}$ Rimbaud.

${ }^{25}$ Jean-Pierre Richard, Poezja i głębia, tłum. Tomasz Swoboda (Gdańsk: Wydawnictwo Słowo/Obraz Terytoria, 2008), 140.
} 
Owo tragiczne i paradoksalne poczucie nietożsamości i rozdwojenia było doświadczeniem zarówno Rimbauda, jak później także Wojaczka, który napisze: „Jest ja / ale mnie nie ma”26. Ślady tego psychicznego i kreacyjnego stanu odnaleźć można w różnych częściach Sezonu $w$ piekle, w lekturze, którą pilnie studiował autor Sezonu. Rimbaud zapisywał na przykład: „Nie mam mnie już na świecie”27, „Prawdziwe życie jest nieobecne. Nie ma nas na świecie”28.

Sezon $w$ piekle to nowatorski cykl napisany prozą poetycką z rzadka przeplataną krótkimi, regularnymi wierszami. Zawarte w nim wizyjne stany, reminiscencje, obrazoburcze wrażenia i wspomnienia stworzyła, jak pisze Krystyna Wojtynek-Musik, „wyobraźnia człowieka głęboko cierpiącego”29. Podobnie zapewne powstał Sezon Wojaczka, o którym Błoński pisał: „Składnia rozpada się, bo rozpada się całkujące poczucie osobowości”30. Tylko wiersz wolny w typie różewiczowskim, w latach 60 . wciąż jeszcze na swój sposób nowatorski, mógł oddać rozbicie i niekoherencję „ja”, balansującego na granicy „ja” i „mnie”. Z tego punktu widzenia Sezon można nazwać Peirce'owskim diagramem:

Diagramatyczność tego typu poezji - wyjaśnia Zofia Mitosek - polegałaby na analogii między nastrojem „ja” lirycznego i dyspozycją tekstu na wersy, strofy oraz stosowaniu interpunkcji. Można by zatem powiedzieć, że wiersz wolny jest ikonem relacji [...] jego budowa metryczna stanowiłaby pochodną semantyki ${ }^{31}$.

Sezon jako wiersz wolny wymaga odczytania z uwzględnieniem konstrukcji graficznej ${ }^{32}$. Jego forma składa się z sześciu cząstek o różnej liczbie wersów, zgrupowanych w następującym układzie: 7, 4, 3, 3, 2, 2. Malejąca liczba wersów w kolejnych strofoidach buduje narastające wrażenie depersonalizacji, zagubienia, utraty poczucia tożsamości. Coraz mniej tekstu w następujących strofoidach przepełnione jest brakiem - milczeniem spowodowanym wzmagającym się lękiem i poczuciem zagrożenia, przerażeniem odkrytego losu. Dialektyka wahań podmiotu uzyskana została grą powtórzeń, paralelizmów, a zarazem ich zaprzeczeń i zaburzeń.

Pierwsza strofoida składa się ze zdań katalogujących paradoksalne zaprzeczenia w schemacie wyrażeń „jest / ale nie ma”:

\author{
Jest poręcz \\ ale nie ma schodów \\ Jest ja \\ ale mnie nie ma \\ Jest zimno
}

\footnotetext{
${ }^{26}$ Różnicę w ujęciu „JA-inny” Rimbauda oraz „ja i mnie” Wojaczka szczegółowo analizuje Pertek - Pertek „ «Jest ja, ale mnie nie ma» - granica poetyckiego szaleństwa Rafała Wojaczka", 221-226. Por. także Niewiadomski, „Wojaczek: nieuchwytna cielesność, nieuchwytne ciało poezji”, 76.

${ }^{27}$ Arthur Rimbaud, „Sezon w piekle”, tłum. Artur Międzyrzecki, w Wiersze. Sezon w piekle. Iluminacje. Listy, wybrał, opracował i posłowiem opatrzył Artur Międzyrzecki (Kraków: Wydawnictwo Literackie, 1993), 169.

${ }^{28}$ Rimbaud, s. 173.

${ }^{29}$ Krystyna Wojtynek-Musik, Terra rhetorica w poezji Rimbauda (Katowice: Wydawnictwo Uniwersytetu Śląskiego, 2006), 83.

${ }^{30}$ Błoński, „Inne lęki, inne bajki”, 88.

${ }^{31}$ Zofia Mitosek, Mimesis. Zjawisko i problem (Warszawa: Wydawnictwo Naukowe PWN, 1997), s. 39.

${ }^{32}$ Witold Sadowski, Wiersz wolny jako tekst graficzny (Kraków: Towarzystwo Autorów i Wydawców Prac Naukowych Universitas, 2004).
} 
ale nie ma ciepłych skór zwierząt

niedźwiedzich futer lisich kit

Uzyskana paralelność powtarzalnych układów demonstrujących jaskrawe zaprzeczenia wprowadza czytelnika w stan niepewności, wywołuje konfuzję już od pierwszego stwierdzenia, by eskalować w wypowiedzi „Jest ja / ale mnie nie ma”. Cała pierwsza strofoida demonstruje stan zawieszenia, alienacji i wyobcowania od świata. Czytelnik zostaje pozostawiony w stanie zagubienia i niepewności, bo druga i trzecia strofoida są zbudowane inaczej, wypowiedź skupiona jest na opisie odczuwalnego stanu mówiącego „ja”:

Od czasu kiedy jest mokro

jest bardzo mokro

ja kocha mokro

na placu, bez parasola

Jest ciemno

jest ciemno jak najciemniej

mnie nie ma

Nietożsamość mówiącego „ja” i „ja” poetyckiego (,ja kocha mokro”, „mnie nie ma”) jest wyraźnie zaznaczona. „Zaimek »ja« - pisał Błoński - rządzi trzecią osobą, jakby dla udowodnienia, że można siebie odczuć jak rzecz lub raczej, że można znaleźć się na zewnątrz siebie samego" ${ }^{33}$.

Powyższy fragment Sezonu odczytywano zarówno w odniesieniu do teorii psychoanalitycznych, jak i Biblii. Zastosowany w języku lirycznego „ja” tryb powtórzenia, tautologii, demonstracyjnej agramatyczności wydaje się sugerować aurę afazji. Barańczak dostrzegał tu stylizację na język dziecka, regresywne, motywowane psychoanalitycznie, wkraczanie na obszar dziecięcej psychiki ${ }^{34}$. Wątek psychoanalityczny podejmował także Komendant, który uściślał:

Regres w dziecięcość [...] jest więc naiwną próbą zawrócenia czasu do punktu wyjścia, stanu pierwotnej harmonii i szczęśliwości, charakterystycznej dla dziecka. [...] Będąc odmową zgody na świat, okazuje się jednak zaprzeczeniem „ja” („Mnie nie ma”), jeszcze jedną utopią Złotego Wieku, do którego powrót jest zakazany - wygnanie jest nieodwracalne ${ }^{35}$.

Motyw wody (,jest mokro") 36 oraz ciemności (,jest ciemno”) można interpretować z punktu widzenia psychoanalizy jako pragnienie powrotu do łona matki, w odniesieniu genezyjskim zaś jako marzenie o powrocie do stanu sprzed stworzenia, gdy „Duch Boży unosił się nad powierzchnią wód"37. W obu przypadkach chodzi o pragnienie uzyskania trwania poprzedzającego życie,

${ }^{33}$ Błoński, „Inne lęki, inne bajki”, 87.

${ }^{34}$ Barańczak, „Rafał Wojaczek. Metafizyka zagrożenia”, 94-96.

${ }^{35}$ Komendant, „Przywracanie symetrii”, 104.

${ }^{36} \mathrm{Na}$ marginesie zagadnienia wody warto wspomnieć o fascynacjach pływackich i żeglarskich Wojaczka, które, jak podkreślają badacze, owocowały pojawieniem się motywów akwatycznych w jego poezji. Zob. na ten temat Bogusław Kierc, Rafał Wojaczek. Prawdziwe życie bohatera (Warszawa: Wydawnictwo W.A.B, 2007), 26; Konrad Wojtyła, Anty-antychryst? Wojaczek religijny, 81-83.

${ }^{37}$ Biblia to jest Pismo Święte Starego i Nowego Testamentu. Nowy przekład z języków hebrajskiego i greckiego opracowany przez Komisję Przekładu Pisma Świętego. (Warszawa: Brytyjskie i Zagraniczne Towarzystwo Biblijne 1980), 7. 
bytowania przed narodzeniem, jeszcze-nie-życia, a może wprost nieistnienia ${ }^{38}$, co jest wyrazem głębokiego, dojmującego lęku egzystencjalnego. Potwierdzeniem tego stanu są zamykające tę strofoidę słowa: „mnie nie ma”. Są one powtórzeniem tego samego stwierdzenia z pierwszej cząstki Sezonu. Tworzy się dzięki temu bardzo silna koda, podkreślająca nieistnienie „mnie”. Jest ona także zapowiedzią kolejnej strofoidy, najbardziej może tragicznej w wyrazie mówiącego „ja”:

Nie ma spać
Nie ma oddychać
Żyć nie ma

Użycie nieosobowych form bezokolicznika ugruntowuje nietożsamość „ja” i potwierdza słowa podmiotu „mnie nie ma”. Uwydatnia ponadto, zauważa Kunz, „skrajnie zdepersonalizowany, bezosobowy charakter doświadczenia" ${ }^{39}$. Zastosowany tok anafory, który w ostatnim wersie zostaje ostentacyjnie zaburzony czy odwrócony, prowadzi do wyakcentowania słowa „żyć”, ale tylko by zakomunikować „żyć nie ma” i utwierdzić narastające w trakcie wiersza przekonanie o trwającym stanie śmierci za życia, czy raczej życia w śmierci. W innym wierszu z tomu Sezon Wojaczek napisze: „Przez sen, przez ciebie / donoszę siebie / do twojej śmierci” ${ }^{40}$.

Ostatnie dwa dystychy wiersza Sezon zawierają intertekstualne odwołanie do tragedii Shakespeare'a Makbet:

Tylko drzewa się ruszają

niepospolite ruszenie drzew

rodzą czarnego kota

który przebiega wszystkie drogi

W pierwszej scenie Makbeta na pustkowiu zjawiają się trzy wiedźmy, będące sprawczyniami mających się zdarzyć nieszczęść. Jednej z nich towarzyszy kot („Nie miaucz tak, idę już, kocurze!” zwraca się ona do zwierzęcia ${ }^{41}$ ). Wiedźmy są pośredniczkami między światem ciemności i magii oraz ziemskim, posłanniczkami Hekate, pilnującymi, by dopełnił się los Makbeta"2 ${ }^{42}$ Zbliżający się do murów zamku Dunsinanu Las Birnamski (posłaniec obwieszczał: „las drgną / I ruszył z miejsca”43) zwiastował jego śmierć. Przeznaczenie Makbeta naznaczone fatum musiało się wypełnić.

Przedstawiona w Sezonie Wojaczka okoliczność przebywania „ja” „na placu” nocą w deszczu staje się okazją by dostrzec znaki tragicznej przyszłości. Wypowiedź podmiotu: „drzewa się ruszają”,

\footnotetext{
${ }^{38}$ Mircea Eliade pisze, że „zanurzenie w wodzie oznacza regres do pierwotnego stanu bezforemności, powrót do stanu preegzystencji pozbawionej kształtów. [...] zanurzenie równoznaczne jest z ich [form] zniweczeniem”. Zob. Mircea Eliade, Obrazy i symbole. Szkice o symbolice magiczno-religijnej, tłum. Magda i Paweł. Rodakowie (Warszawa: Wydawnictwo Aletheia, 2009), 209-210.

${ }^{39} \mathrm{Kunz}$, „Więcej niż słowa. «Nie skończona krucjata» Rafała Wojaczka”, 289.

${ }^{40}$ Rafał Wojaczek, „Umiem być ciszą”, w Wiersze, wybrał i posłowiem opatrzył Tadeusz Pióro (Warszawa: PIW, 2004$), 41$.

${ }^{41}$ William Shakespeare, Makbet, tłum. Stanisław Barańczak (Poznań: Wydawnictwo „W drodze”, 1992), 9.

${ }^{42} \mathrm{~W}$ chacie w obecności Wiedźm i Hekate Trzecia Zjawa przepowiada los Makbeta: „Bądź jak lew władczy [...] Dopóki szturmem pod mur Dunsinanu / Nie dojdzie wrogi Las Birnamski”. Zob. Shakespeare, Makbet, 98.

${ }^{43}$ Shakespeare, 137.
} 


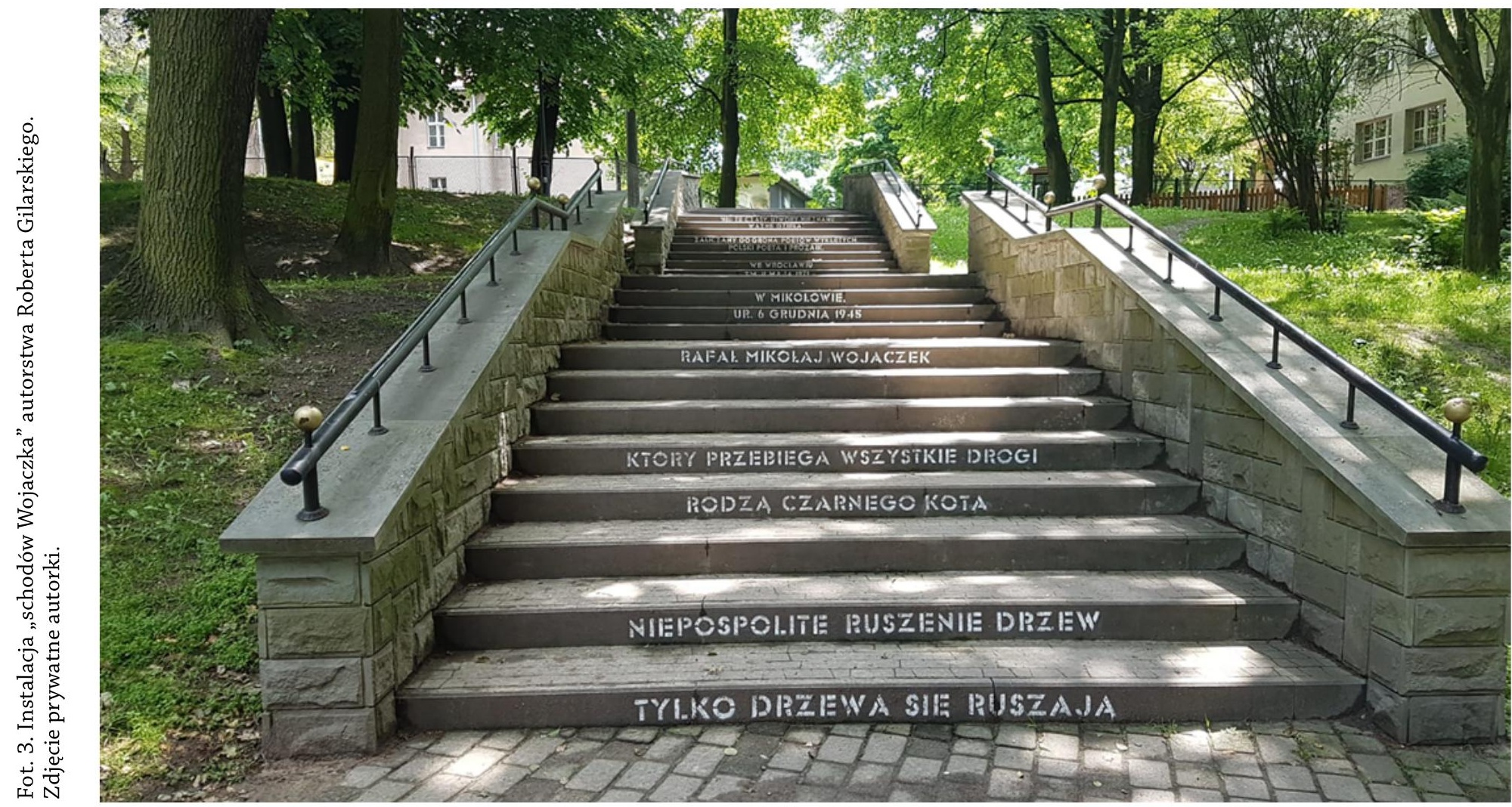

„niepospolite ruszenie drzew” i widok „czarnego kota”, który ma związek z ciemnością i śmiercią ${ }^{44}$, a zarazem zwiastuje nieszczęście, stają się, na wzór dramatu Makbeta, przepowiednią nieszczęść i sygnałami ciążącego nad poetą fatum. Tragiczny los oraz nadchodząca śmierć są, w domyśle czy przeczuciu „ja”, jego przeznaczeniem. W dodatku czarny kot „przebiega wszystkie drogi”, unaoczniając nieuchronność i bezwyjściowość egzystencjalnej sytuacji. „Wyrok na mnie już zapadł” - napisał Wojaczek we wczesnym Poemacie opatrzonym datą 1964 roku ${ }^{45}$. Poeta, zauważa Wojtyła, „nie mogąc uciec przeznaczeniu, czyni życie niemożliwym do życia”46. Świadomość tragicznie naznaczonej przyszłości, zapisana już w debiutanckim tomie, towarzyszyła Wojaczkowi do końca życia. W zbiorze Którego nie było zamieszczony jest następujący dystych:

Musi być ktoś, kogo nie znam, ale kto zawładnął

Mną, moim życiem, śmiercią; tą kartką ${ }^{47}$

Podobne słowa mógłby w zakończeniu tragedii wypowiedzieć również Makbet.

Cudak zauważał, że „wyobraźnia poetycka autora Sezonu ma charakter przede wszystkim wyobraźni językowej, dla której świat jawi się nie pod postacią przedmiotów, ale symbolizujących je zdarzeń semantycznych"48. Tak właśnie jest w analizowanym wierszu Sezon, gdzie rzeczywistość przedsta-

\footnotetext{
${ }^{44}$ Juan Eduardo Cirlot, Słownik symboli, tłum. Ireneusz Kania (Kraków: Wydawnictwo Znak, 2000), 199-200.

${ }^{45}$ Rafał Wojaczek, „Poemat”, Nie te czasy. Utwory nieznane (Mikołów: Instytut Mikołowski, 2016), 7. Szczegółową interpretację Poematu Wojaczka przedstawił Konrad Wojtyła, Anty-antychryst? Wojaczek religijny, 260-292.

${ }^{46}$ Wojtyła, Anty-antychryst? Wojaczek religijny, 231.

${ }^{47}$ Rafał Wojaczek, „Musi być ktoś”, w Wiersze, wybrał i posłowiem opatrzył Tadeusz Pióro (Warszawa: Wydawnictwo PIW, 2004), 262.

${ }^{48}$ Cudak, Inne bajki. W kregu liryki Rafała Wojaczka, 82.
} 
wiona w postaci elementów topografii zadrzewionego placu odsyła do intertekstualnych nawiązań, które w dialogicznych relacjach odsłaniają psychosferę lirycznego „ja”. Co jednak się stanie, gdy wiersz jako instalacja odczytany zostanie na schodach parku w otoczeniu drzew i w towarzystwie przebiegających kotów? Jak zmienia się percepcja tekstu Wojaczka na mikołowskich Plantach?

W instalacji wersy Sezonu zostały zapisane na podstopnicach parkowych schodów. Wchodząc, można odczytywać kolejne linijki wiersza ${ }^{49}$. Forma graficzna utworzona pierwotnie przez Wojaczka i wydrukowana następnie na stronie w tomiku została tym samym przetransponowana na topografię terenu, na stopnie, po których można wejść wyżej. Każdy wers stał się schodem, można powiedzieć, bruzdą wytyczoną w terenie. Ujawnia się dzięki temu związek zapisu wiersza z pierwotnym znaczeniem pisma. Słowo „wiersz” pochodzi od łacińskiego versŭs W polszczyźnie przez wieki nazwą „wiersz” obejmowano zarówno linijkę tekstu (dzisiejszy wers), jak i cały utwór wierszowany ${ }^{50}$. Jeszcze w 1912 roku Kazimierz Wóycicki, pisząc o wierszach, miał na uwadze wersy („Środkowe przepołowienie wierszy, zwane średniówką” - notował ${ }^{51}$ ). W drugiej połowie dwudziestego wieku w polskich badaniach wersologicznych przyjęto, że „wers jest podstawową jednostką strukturalną wiersza" ${ }^{2}$, jak pisała Lucylla Pszczołowska. W nowszych badaniach, opartych nadal na teorii prozodyjnej, wers, jak ujmuje to Adam Kulawik, „to segment tekstu zawarty pomiędzy kolejnymi pauzami wersyfikacyjnymi, które są dla niego konstytutywne" ${ }^{\text {. }}$.

Łacińskie słowo versŭs znaczy 'bruzda, linia, szereg', czasownik versō oznacza 'często obracać, kręcić, zwracać, toczyć, przewracać ${ }^{54}$. Derrida wywodzi zapis wiersza w postaci pisma liniowego z kultury agrarnej:

Bruzda [sillon] to linia, ślad zostawiany przez rolnika: droga - via rupta - rozłupana przez lemiesz pługa. Bruzda rolnictwa, jak sobie przypominamy, otwiera naturę na kulturę. A wiadomo również, że pismo rodzi się wraz z rolnictwem, które nie może się obyć bez osiadłości ${ }^{55}$.

Instalacja przedstawiająca wiersz Wojaczka w bruzdach schodów na wzniesieniu parkowym przypomina o pierwotnym związku zapisu pisma liniowego, wzorowanego na uwidaczniających się skibach ziemi, układających się w równe szeregi przeoranego pola. „Schody Wojaczka" nawiązują ponad czasem relację ze źródłową tradycją, przywołują ją jako kontekst

\footnotetext{
${ }^{49}$ Topograficznego zapisu Sezonu Wojaczka na schodach w mikołowskim parku nie można łączyć z formalnowersyfikacyjnym zagadnieniem „schodków” wierszowych (np. Majakowskiego), gdzie wers zostaje rozbity na kilka linijek graficznych, napisanych na różnych poziomach. Wiersz Wojaczka w instalacji odtwarza bowiem układ formy z edycji książkowej, w której nie występuje „schodkowe” rozłamanie wersu. Na temat „schodków” w rozczłonkowaniu wersu zob. Lucylla Pszczołowska, „Wers”, w Wiersz. Podstawowe kategorie opisu. Cz. 1. Rytmika, red. Jerzy Woronczak (Wrocław: Zakład Narodowy imienia Ossolińskich, Wydawnictwo PAN, 1963), 84-85; Witold Sadowski, „Schodki”, w Wiersz wolny jako tekst graficzny (Kraków: Towarzystwo Autorów i Wydawców Prac Naukowych Universitas, 2004), 148-151.

${ }^{50}$ Wioletta Bojda, Aleksander Nawarecki, „Wiersz”, w Ilustrowany słownik terminów literackich. Historia, anegdota, etymologia, red. Zbigniew Kadłubek, Beata Mytych-Forajter, Aleksander Nawarecki (Gdańsk: Wydawnictwo Słowo/ Obraz Terytoria, 2018), 507-511.

${ }^{51}$ Kazimierz Wóycicki, Forma dźwiękowa prozy polskiej i wiersza polskiego (Warszawa: Wydawnictwo PWN, 1960), 69.

${ }^{52}$ Pszczołowska, „Wers”, 82.

${ }^{53}$ Adam Kulawik, Wersologia. Studium wiersza, metru i kompozycji wersyfikacyjnej (Kraków: Wydawnictwo Antykwa, 1999), 55.

${ }^{54}$ Słownik łacińsko-polski, oprac. Kazimierz Kumaniecki (Warszawa: Wydawnictwo Szkolne PWN, 2001), 452-453. Czasownik versō oznacza także między innymi: 'wykładać, wyjaśniać; rozmyślać, rozważać; miotać, niepokoić, męczyć, dręczyć', co także, można przyjąć, wiąże się z wierszem.

${ }^{55}$ Derrida, O gramatologii, 366-367.
} 
współczesnej kultury. Wers tekstu wpisuje się w obszar ziemi. Szeregi schodów, wyznaczając linie wersów, odtwarzają zapis wiersza, pierwotne pismo mowy.

Robert Gilarski w artystycznym zamyśle zadbał, by wizualizacja wiersza na „schodach Wojaczka” odtwarzała autorską formę Sezonu z utrzymaniem delimitacji tekstu utrwalonej w tomiku. Zachowane zostały pauzy między strofoidami, czy raczej linijki puste ${ }^{56}$, dzięki czemu utwór w wyniku transpozycji nie został przekształcony $\mathrm{w}$ formę stychiczną. Zapis typograficzny wydrukowany w książce został w artystycznym przetworzeniu zastąpiony zapisem piktorialnym na stopniach w parku, z tą różnicą, że uległ graficznemu wyśrodkowaniu. Zabieg ten, który okazał się niezwykle fortunny zarówno dla efektów obrazowych, jak i percepcyjnych, koncentruje słowa w osi przebiegu spaceru. Odczytując tekstową wizualizację w trakcie wchodzenia po schodach, otrzymujemy przewidziane w strukturze wiersza delimitacyjne pauzy, momenty chwilowego zawieszenia lektury i toku myśli. Podobnie jak w trakcie odczytywania wiersza opublikowanego w książce, w przestrzeni publicznej parku następuje „wydarzenie lektury” ${ }^{57}$. „Dążąc od wersu do wersu - pisze Artur Grabowski o aktualizacji typograficznej - wciąż kończy się i zaczyna proces czytania, wciąż kończy się i zaczyna wiersz"58. Parafrazując, można powiedzieć, że w mikołowskiej instalacji, dążąc od stopnia-wersu do stopnia-wersu, wciąż kończy się i zaczyna proces czytania, kończy się i zaczyna wiersz.

Warto jednak podkreślić, że schody wbudowane w rozległą przestrzeń zbocza na Plantach nie są równej wielkości, część schodów jest krótsza, przez co przechodzi się przez nie szybciej, część zaś ma charakter szerokiego podestu, przejście przez nie zajmuje więcej czasu. Przejście po nich jest więc zróżnicowane, pokonywanie terenu następuje nieregularnie, co wpływa na odczytywanie wiersza. Architektura schodów generuje proces lektury, wydłużając pewne pauzy między strofoidami. W wizualizacji na przykład miejsce dwu cząstek tekstu:

\author{
Jest ciemno \\ jest ciemno jak najciemniej \\ mnie nie ma \\ Nie ma spać \\ Nie ma oddychać \\ Żyć nie ma
}

przypadło na stopnie szerokie, co sprawiło, że odległość między stopniami-wersami stała się większa. Wpływa to na odbiór tekstu, sprzyja pogłębionej refleksji skupionej na niejako wyodrębnionej linijce. Każdy z wersów percypowany jest autonomicznie, rozciągając czas rodzących się emocji. Słowa podmiotu odkrywane na schodach wydają się jeszcze bardziej dramatyczne i tragiczne. Wchodzenie w górę i odczytywanie Sezonu prowadzi, zgodnie z zamysłem instalacji Gilarskiego, wprost do muralu z podobizną Wojaczka, czyniąc lekturę wiersza silnie osadzoną w kontekście biograficznym ${ }^{59}$.

\footnotetext{
${ }^{56} \mathrm{Na}$ temat linijki pustej zob. Sadowski, Wiersz wolny jako tekst graficzny, 109-113.

${ }^{57}$ Artur Grabowski, Wiersz. Forma i sens (Kraków: Towarzystwo Autorów i Wydawców Prac Naukowych Universitas, 1999), 84.

${ }^{58}$ Grabowski, 44.

${ }^{59}$ Biograficzny kontekst pogłębia dodatkowo umiejscowienie muralu z podobizną Wojaczka obok szkoły, do której uczęszczał poeta. W sąsiedztwie znajduje się także obecny budynek Instytut Mikołowskiego im. Rafała Wojaczka.
} 
Sezon Wojaczka zgodnie z tą świadomością odczytujemy w tomiku wertykalnie, percypujemy treść kolejnych wersów, grupowanych w strofoidach. Przesuwamy wzrok w dół strony, koncentrując uwagę na frazach emocyjnego skupienia, charakterystycznych dla wiersza w typie różewiczowskim. „Krótkie linijki takiego wiersza - pisze Grabowski - prowadzą naszą uwagę w pionie, idziemy po śladach jakiegoś procesu”62. W Sezonie poznajemy sytuację psychotyczną „ja”, jego poczucie nietożsamości, pragnienie nieistnienia, wreszcie lęk wywołany odkryciem ciążącego na nim fatum. Lektura pionowa wzmocniona efektami powtórzenia, paralelizmu i anafory stopniowo pozwala dostrzec nasilające się sygnały destabilizacji psychicznej podmiotu, podążającego niejako drogą w dół ku sezonom piekła. Tymczasem wizualizacja wiersza na schodach w Mikołowie narzuca poprzez topografię terenu lekturę wertykalną w górę. Idąc wzwyż, odczytujemy wiersz w ruchu wznoszącym, przesuwając wzrokiem z podstopnicy na podstopnicę. Różnica trybu percepcji tekstu ma zasadnicze znaczenie dla interpretacji liryku Wojaczka. Zmiana lektury pionowej „w dół” na lekturę „w górę” zdeterminowana zostaje odniesieniami symbolicznymi, co wpływa na semantykę tekstu. Wiersz czytany na stronie książki, przywołujący intertekstualne nawiązanie do Sezonu w piekle, kształtuje przekonanie o pogrążaniu się wewnętrznym podmiotu, o podążaniu w dół, do śmierci. Staje się ona nieunikniona, bo została mu pisana i przepowiedziana znakami, co sprawia, że nie ma żadnej nadziei, jest tylko czarna, naznaczona mortalnie przyszłość. Wizualizacja na schodach w parku, wymuszająca lekturę „do góry”, do horyzontu wzgórza, przypominająca raczej „schody do nieba”, otwiera wiersz mikołowskiego poety na problematykę transcendencji. „Bóg - pisał Wojtyła - [...] jest jedną z głównych figur w poezji Wojaczka, a kwestie religijne są fundamentalne dla zrozumienia całego dzieła i ukrytych w nim sensów"63. Sezon, jako młodzieńczy utwór otwierający debiutancki tom poezji, wprowadzał najważniejsze zagadnienie tej twórczości, którym jest śmierć. Instalacja w Mikołowie aktualizuje drugi, wyłaniający się z późniejszych utworów, problem teologii i eschatologii. „Centralną figurą w twórczości Rafała Wojaczka jest "śmierć«, drugą, bez której nie sposób mówić o pierwszej, "Bóg“" - pisał Wojtyła. Autor pracy Anty-Antychryst? zaznaczał, że „Wojaczek był "poetą religijnym«, więc jego twórczość daje się - a nawet powinno - odczytywać jako »religijnąu”"64. Taką perspektywę interpretacji zarysowuje dzisiaj wizualizacja Sezonu w mieście urodzenia poety, trudno jednak było doszukiwać się jej w utworze wydrukowanym w tomiku.

Usytuowanie instalacji wiersza Sezon na schodach mikołowskich Plant wprowadza dodatkowe znaczenia i dokonuje, powiedziałby Grabowski, semiotyzacji kontekstu65. „Forma dzieła sztuki - tłumaczy - przenosi się na zewnątrz, dematerializuje się w samej przestrzeni semiotycznej, która przez to nasiąknięcie nabiera niespotykanej dotąd mocy kreacyjnej”66. Przestrzeń semiotyczną dla artystycznej wizualizacji wiersza Wojaczka tworzą drzewa oraz schody parkowe zlokalizowane w Mikołowie. Co ciekawe, być może prototyp schodów z wiersza (których w istocie nie ma, bo jest tylko poręcz) znajduje się na terenie Kliniki Psychiatrycznej Akademii Medycz-

\footnotetext{
${ }^{62}$ Grabowski, 77.

${ }^{63}$ Wojtyła, Anty-antychryst? Wojaczek religijny, 107. Wojtyła zwraca uwagę, że „poeta ze Śląska jawi się spadkobiercą i świadomym kontynuatorem tradycji teologicznej, którą nie tylko się inspiruje, ale też twórczo, nierzadko bluźnierczo, ją rekontekstualizuje i zniekształca. Ewokuje myślenie sakralne, a w ślad za tym "przepisanie« tej tradycji za pomocą wątków profanicznych; restytucja sacrum odbywa się z kolei głównie przez negację" (s. 11).

${ }^{64}$ Wojtyła.

${ }^{65}$ Grabowski, Wiersz. Forma i sens, 60.

${ }^{66}$ Grabowski, 59 .
} 
do lektury intersemiotycznej, otwartej na kontekst miasta, włączającej topografię okolicy do konotowanych znaczeń. Jednocześnie jest interwencją w sam proces lektury i poznawania struktury utworu literackiego, jego formy, wewnętrznej architektoniki. Bruzdy schodów wkraczają jako proceder w stan wersyfikacyjnych oczekiwań, zaburzają pojęcie grafemicznej tekstury utworu. „Schody” wreszcie odwracają tradycyjny, mówiąc za Ingardenem, „porządek następstwa" typowy dla odbioru dzieła literackiego. Przejście po stopniach wzwyż, będące analogonem lektury, objawia się jako metanoja.

\section{Bibliografia}

Barańczak, Stanisław. „Rafał Wojaczek. Metafizyka zagrożenia". W Który jest. Rafaz Wojaczek w oczach przyjaciót, krytyków i badaczy. Zredagowane przez Romuald Cudak i Maciej Melecki, 93-101. Katowice-Mikołów: Wydawnictwo Uniwersytetu Śląskiego, Instytut Mikołowski, 2001.

Biblia to jest Pismo Święte Starego i Nowego Testamentu. Nowy przekład z języków hebrajskiego i greckiego opracowany przez Komisję Przekładu Pisma Świętego. Warszawa: Brytyjskie i Zagraniczne Towarzystwo Biblijne, 1980.

Błoński, Jan. „Inne lęki, inne bajki”. W Który jest. Rafał Wojaczek w oczach przyjaciót, krytyków i badaczy. Zredagowane przez Romuald Cudak i Maciej Melecki, 87-92. Katowice-Mikołów: Wydawnictwo Uniwersytetu Śląskiego, Instytut Mikołowski, 2001.

Bojda, Wioletta; Nawarecki, Aleksander. „Wiersz”. W Ilustrowany słownik terminów literackich. Historia, anegdota, etymologia, 507511. Zredagowane przez Zbigniew Kadłubek, Beata Mytych-Forajter, Aleksander Nawarecki. Gdańsk: Wydawnictwo Słowo/Obraz Terytoria, 2018.

Cirlot, Juan Eduardo. Stownik symboli, przetłumaczone przez Ireneusz Kania. Kraków: Wydawnictwo Znak, 2000.

Cudak, Romuald. Inne bajki. W kręgu liryki Rafała Wojaczka. Katowice: Wydawnictwo Uniwersytetu Śląskiego, 2004.

Derrida, Jacques. O gramatologii, przetłumaczone przez Bogdan Banasiak. Łódź: Wydawnictwo Officyna, 2011.

Dybel, Paweł. Ziemscy, słowni, cieleśni. Eseje o polskich poetach wspótczesnych. Mikołów: Instytut Mikołowski, 2019.
Eliade, Mircea. Obrazy i symbole. Szkice o symbolice magiczno-religijnej, przetłumaczone przez Magda i Paweł Rodakowie. Warszawa: Wydawnictwo Aletheia, 2009.

Grabowski, Artur. Wiersz. Forma i sens. Kraków: Towarzystwo Autorów i Wydawców Prac Naukowych Universitas, 1999.

Karpowicz, Tymoteusz. „Debiuty. Rafał Wojaczek". Poezja, nr 1 (1965): 65.

-———. „Sezon na ziemi”. W Który jest. Rafał Wojaczek w oczach przyjaciót, krytyków i badaczy. Zredagowane przez Romuald Cudak i Maciej Melecki, 131-153. Katowice-Mikołów: Wydawnictwo Uniwersytetu Śląskiego, Instytut Mikołowski, 2001.

Kierc, Bogusław. Rafał Wojaczek. Prawdziwe życie bohatera. Warszawa: Wydawnictwo W.A.B, 2007.

Komendant, Tadeusz. „Przywracanie symetrii. O poezji Rafała Wojaczka”. W Który jest. Rafał Wojaczek w oczach przyjaciót, krytyków i badaczy. Zredagowane przez Romuald Cudak i Maciej Melecki, 102-112. Katowice-Mikołów: Wydawnictwo Uniwersytetu Śląskiego, Instytut Mikołowski, 2001.

Kulawik, Adam. Wersologia. Studium wiersza, metru i kompozycji wersyfikacyjnej. Kraków: Wydawnictwo Antykwa, 1999.

Kunz, Tomasz. „Liryka Rafała Wojaczka: przemiany podmiotu poetyckiego". W Który jest. Rafał Wojaczek w oczach przyjaciót, krytyków $i$ badaczy. Zredagowane przez Romuald Cudak i Maciej Melecki, 217-245. Katowice-Mikołów: Wydawnictwo Uniwersytetu Śląskiego, Instytut Mikołowski, 2001.

——. „Więcej niż słowa. «Nie skończona krucjata» Rafała Wojaczka”. W Interpretować 
dalej. Najważniejsze polskie książki poetyckie lat 1945-1989, 285-294. Zredagowane przez Anna Kałuża, Alina Świeściak. Kraków: Towarzystwo Autorów i Wydawców Prac Naukowych Universitas, 2011.

Łukasiewicz, Jacek. „Liryka Rafała Wojaczka”. W Który jest. Rafał Wojaczek w oczach przyjaciót, krytyków i badaczy. Zredagowane przez Romuald Cudak i Maciej Melecki, 162-171. Katowice-Mikołów: Wydawnictwo Uniwersytetu Śląskiego, Instytut Mikołowski, 2001.

Mitosek, Zofia. Mimesis. Zjawisko i problem. Warszawa: Wydawnictwo Naukowe PWN, 1997.

Niewiadomski, Andrzej. „Wojaczek: nieuchwytna cielesność, nieuchwytne ciało poezji”, Kresy, nr 4 (2007): 69-90.

Pertek, Grzegorz. „ «Jest ja, ale mnie nie ma» - granica poetyckiego szaleństwa Rafała Wojaczka”. Przestrzenie Teorii, nr 16 (2011): 205-235.

Pszczołowska, Lucylla. „Wers”. W Wiersz. Podstawowe kategorie opisu. Cz. 1. Rytmika. Zredagowane przez Jerzy Woronczak. Wrocław: Zakład Narodowy imienia Ossolińskich, Wydawnictwo PAN, 1963.

Richard, Jean-Pierre. Poezja i głębia. Przetłumaczone przez Tomasz Swoboda. Gdańsk: Wydawnictwo Słowo/Obraz Terytoria, 2008.

Rimbaud, Arthur. „List do Jerzego Izambarda, Charleville, (13) maj 1871”. Przetłumaczone przez Julia Hartwig, Artur Międzyrzecki, 300-301. W Wiersze. Sezon w piekle. Iluminacje. Listy, wybrał, opracował i posłowiem opatrzył Artur Międzyrzecki. Kraków: Wydawnictwo Literackie, 1993.

\footnotetext{
_-_- „Sezon w piekle”. Przetłumaczone przez Artur Międzyrzecki. W Wiersze. Sezon $w$ piekle. Iluminacje. Listy, wybrał, opracował i posłowiem opatrzył Artur Międzyrzecki, 157-197. Kraków: Wydawnictwo Literackie, 1993.
}

Sadowski, Witold. Wiersz wolny jako tekst graficzny. Kraków: Towarzystwo Autorów i Wydawców Prac Naukowych Universitas, 2004.

Shakespeare, William. Makbet. Przetłumaczone przez Stanisław Barańczak. Poznań: Wydawnictwo „W drodze”, 1992.

Słownik łacińsko-polski. Oprac. Kazimierz Kumaniecki. Warszawa: Wydawnictwo Szkolne PWN, 2001.

Wojaczek, Rafał. Nie te czasy. Utwory nieznane. Mikołów: Instytut Mikołowski, 2016.

Reszta krwi. Zredagowane przez Maciej Melecki. Mikołów: Instytut Mikołowski, 1999.

Sanatorium. Wrocław: Biuro

Literackie, 2010.

Wiersze. Wybrał i posłowiem opatrzył Tadeusz Pióro. Warszawa: Wydawnictwo PIW, 2004.

Wojtyła, Konrad. Anty-antychryst? Wojaczek religijny. Mikołów: Instytut Mikołowski, 2021.

Wojtynek-Musik, Krystyna. Terra rhetorica w poezji Rimbauda. Katowice: Wydawnictwo Uniwersytetu Śląskiego, 2006.

Wóycicki, Kazimierz. Forma dźwiękowa prozy polskiej i wiersza polskiego. Warszawa: Wydawnictwo PWN, 1960. 


\title{
SŁOWA KLUCZOWE:
}

\author{
Rafaz Wojaczek
}

\section{Sezon}

\section{W I E R S Z W O L N Y}

\begin{abstract}
Abstrakt:
Artykuł odwołuje się do pracy street art Roberta Gilarskiego znajdującej się na Plantach w Mikołowie, w której dokonano wizualizacji wiersza Rafała Wojaczka Sezon. Instalacja prezentuje utwór mikołowskiego poety zapisany na stopniach parkowych schodów. Autorka artykułu interpretuje utwór, a następnie rozważa różnicę między semantyka formy Sezonu utrwaloną $\mathrm{w}$ druku oraz w pracy street art. Zwraca uwagę na wpływ topografii terenu, analizuje transpozycję formy wiersza w zapis piktorialny, gdzie istotną rolę pełnią schody-wersy. Najbardziej radykalna zmiana zachodzi w trybie lektury wertykalnej, wyznaczonej kierunkiem wchodzenia po stopniach-wersach „do góry”. Zmiana wersyfikacyjnych oczekiwań nie pozostaje bez konsekwencji dla interpretacji utworu. Odwrócony porządek odczytywania wiersza w instalacji ma znamiona prowokacji artystycznej i objawia się jako metanoja.
\end{abstract}




\section{NOTA O AUTORCE:}

Joanna Dembińska-Pawelec - dr hab. prof. UŚ. Pracuje w Instytucie Literaturoznawstwa na Wydziale Humanistycznym Uniwersytetu Śląskiego. Prowadzi badania z zakresu poezji współczesnej, genologii oraz interferencji literatury i sztuki. Autorka książek: Światy możliwe w poezji Stanisława Barańczaka (1999), Villanella. Od Anonima do Barańczaka (2006), „Poezja jest sztukq rytmu”. O świadomości rytmu w poezji polskiej dwudziestego wieku (Miłosz - Rymkiewicz - Barańczak) (2010), Arabeska. Szkice o poezji (2013). Publikowała m.in. w „Pamiętniku Literackim”, „Poznańskich Studiach Polonistycznych”, „Acta Universitatis Lodziensis”, „Ruchu Literackim”, „Śląskich Studiach Polonistycznych”. 